\title{
Microstructure and mechanical properties of rapidly solidified FeAlCr intermetallic compound
}

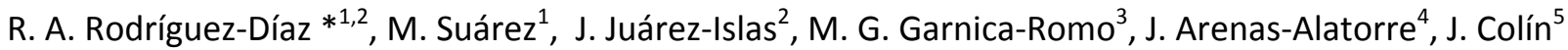 \\ ${ }^{1}$ Departamento de Ingeniería Metalúrgica, Facultad de Química, Universidad Nacional Autónoma de México, (UNAM). \\ Circuito Institutos s/n Edificio “D”, Ciudad Universitaria, México 04510 DF, México. *rardiaz@iim.unam.mx \\ ${ }^{2}$ Instituto de Investigaciones en Materiales, UNAM, Circuito Exterior S/N, Cd. \\ Universitaria, México, DF 04510, México. \\ ${ }^{3}$ Facultad de Ingeniería Civil, UMSNH, Morelia, Michoacán. 58000, México. \\ ${ }^{4}$ Instituto de Física, UNAM, Circuito Exterior S/N, Cd. Universitaria, México, DF 04510, México. \\ ${ }^{5}$ Facultad de Ciencias Químicas, Universidad Autónoma del Estado de Morelos, \\ Av. Universidad 1001. Col. Chamilpa. Cuernavaca, Morelos. C. P. 62209
}

\begin{abstract}
In this work results regarding microstructural characterization of a melt-spun intermetallic compound $\mathrm{Fe} 40 \mathrm{Al} 5 \mathrm{Cr}$ (\% at.) produced by rapid solidification employing the melt spinning technique at three different tangential wheel speeds (12, 16 and $20 \mathrm{~ms}^{-1}$ ) are presented. Melt spun ribbons were characterized by optical and scanning electron microscopy (SEM) in order to observe morphology, grain size, ribbon thickness and also fracture surfaces after tensile tests. EDS coupled to SEM was employed to perform punctual and scan line chemical analyses on samples, $x$-ray diffraction (XRD) was utilized to identify crystal structure and phases. Transmission electron microscopy (TEM) was employed to confirm crystal structure and also to characterize nanopores formed in the specimens by vacancy clustering. With regard to mechanical properties, micro hardness Vickers measurements as well as tensile tests at room temperature were applied to the rapidly solidified ribbons.

The grain size of rapidly solidified Fe40Al5Cr ribbons suffered a drastic reduction as compared with alloys of the same composition produced by conventional melting and casting methods, and in melt-spun ribbons it decreases as the wheel speed increases. Punctual and line-scanning chemical analyses revealed that $\mathrm{Cr}$ enters in solid solution in FeAl matrix. Hardness measurements revealed a softening in rapidly solidified FeAICr ribbons as compared with FeAl alloys and tensile test exhibited a (transgranular + intergranular) mode of fracture, reaching up to $3 \%$ of elongation in FeAlCr alloys. The presence of porous (meso and nano) were also characterized.
\end{abstract}

Keywords: Rapid-solidification, melt-spun-ribbons, microstructure, mechanical properties, porous.

\section{RESUMEN}

En este trabajo se presentan resultados concernientes a la caracterización microestructural de cintas de aleación Fe40Al5Cr que fueron producidas mediante solidificación rápida empleando la técnica de melt-spinning (rueda girante), a tres diferentes velocidades tangenciales de rueda $\left(12,16\right.$ y $\left.20 \mathrm{~ms}^{-1}\right)$. Las cintas solidificadas rápidamente fueron caracterizadas mediante microscopía óptica y electrónica, con el propósito de observar morfología, tamaño de los granos y espesor de las cintas y también observar las superficies de fractura después de los ensayos de tensión en las cintas metálicas. Asimismo, se realizaron análisis químicos puntuales mediante EDS y de barrido en línea, también se realizaron análisis de rayos X (DRX) con el objeto de determinar la estructura cristalina, constantes de red y fases. De la misma manera, los especímenes se observaron mediante microscopía electrónica de transmisión (MET) con la finalidad de confirmar la estructura cristalina y caracterizar nanoporos formados en los especímenes originados por la aglomeración de vacancias. Respecto a las propiedades mecánicas, las cintas fueron sometidas a ensayos de dureza y tensión a temperatura ambiente en aire.

Se observó que el tamaño de grano de las cintas solidificadas rápidamente sufrió un considerable decremento en comparación con aleaciones de la misma composición producida por métodos convencionales de producción, además, tanto el espesor de las cintas como el tamaño de grano se redujeron con el incremento de velocidad de rueda o rapidez de enfriamiento. Los análisis químicos puntuales y de barrido en línea revelaron que el cromo entra en solución solida en la matriz FeAl. Los mesoporos superficiales, así como también los nanoporos observados en el interior de las cintas fueron caracterizados mediante microscopía electrónica. Los ensayos de dureza revelaron un ablandamiento del material en las cintas de aleación ternaria FeAICr en comparación con cintas de aleación binaria FeAl producidas por solidificación rápida. Los ensayos de tensión revelaron un modo de fractura mixto (intergranular + transgranular) con un $3 \%$ de elongación total.

Palabras clave: Solidificación rápida, cintas solidificadas rápidamente, microestructura, propiedades mecánicas, poros. 


\section{Introduction}

Iron aluminides exhibit a great number of desirable properties that include low density, resistance at high temperature, stiffness, oxidation and sulfidation resistance $[1,2]$. However, these intermetallics have limited applications because of their low ductility at room temperature and low impact failure resistance [3]. In order to reduce embrittlement mechanism and improve the ductility of these materials, methodologies, such as macro and micro alloying with elements $\mathrm{Ti}, \mathrm{V}, \mathrm{Nb}$, $\mathrm{Ta}, \mathrm{Cr}, \mathrm{Mo}, \mathrm{W}, \mathrm{Si}$ and $\mathrm{Ni}$ [4], have been developed. Conventional ingot production route suffers from insufficient ductility at low temperature to allow adequate fabrication methods. Powder metallurgy is an alternative methodology where the molten metal is atomized by a gas or liquid flow at elevated velocity in order to produce a rapid solidified powder that can be subsequently consolidated. The "chill block melt spinning" technique [5] is a convenient method to study the potential of rapid solidification where little amounts of alloy are prepared and converted to metallic ribbons under a controlled atmosphere with cooling rates of about $10^{6} \mathrm{~K} / \mathrm{s}$.

The production of intermetallics by rapid solidification has the following potential advantages: a) refinement of microstructure, so that any composition segregation occurs only through short distances needing short thermal treatments to achieve uniformity; b) the potential for extending the solid solubility of ternary elements beyond equilibrium compositions.

Ductility of Fe40Al5Cr alloy has been scarcely reported in few investigations, where these limited investigations have produced the alloys by extrusion with subsequent annealing and have studied the effect of the processing technique upon microstructure and mechanical properties.
O. Klein [6] and collaborators fractured a $\mathrm{Fe} 40 \mathrm{Al} 5 \mathrm{Cr}$ alloy under tension tests in air at room temperature that was processed by doubly extrusion at $(1273 \mathrm{~K}, 7: 1$ and $1023 \mathrm{~K}, 6: 1)$ and annealed at $\left(660{ }^{\circ} \mathrm{C} / 48 \mathrm{~h}+400{ }^{\circ} \mathrm{C} / 120 \mathrm{~h}\right)$. They observed elongation values of $2 \%$ and $2.2 \%$ in the alloys with grain size of $5 \mu \mathrm{m}$ that were tested at a deformation rates of $1 \times 10^{-6}$ and $1 \times 10^{-} \mathrm{s}^{-1}$ during tensile tests. However, $\mathrm{O}$. Klein and collaborators observed particles of $\mathrm{Cr}_{2} \mathrm{Al}$ on fracture surfaces, which originated an increment in yield strength with a simultaneous reduction of ductility. In order to avoid the precipitation of $\mathrm{Cr}_{2} \mathrm{Al}$ particles that could limit the deformation capability of these alloys, rapid solidification processing could have a positive effect on ductility of these fragile alloys because it provides the benefit of extending the solid solubility of solute elements. Therefore, the purpose of this work is to report the effect of rapid solidification of FeAl intermetallic compound macroalloyed with chromium on the microstructure in terms of the lattice parameter, grain size, solute element solubility and mechanical properties.

\section{Experimental procedure}

Fe40Al5Cr alloy was produced by vacuum induction melting by pouring the liquid melt into a rectangular cooper mold. The produced ingot was crushed to form coarse particles, which were remelted in a quartz tube nozzle with a $1 \mathrm{~mm}$ orifice diameter and then rapidly solidified to room temperature using a melt spinning equipment under argon atmosphere. During the melt spinning experiments, an eject pressure of argon of 4 Psi was employed, as well as cooper wheel speeds of 12,16 and $20 \mathrm{~ms}^{-1}$ to achieve cooling rates of $0.715 \times 10^{6}$ to $1.38 \times 10^{6} \mathrm{~K} / \mathrm{s}$. 
Metallographic preparation of specimens was performed by grinding the specimens from 240 to 1500 grit paper and polished with $1 \mu \mathrm{m}$ alumina powder. Then, the melt-spun ribbons were etched with a Keller reagent in order to observe grain size and morphology, photomicrographs of representative areas were obtained with an Olympus-zeiss optical microscope, with an interface toward a PC equipped with image analyzer software (IMAGE PROPLUS). The grain size was determined by the linear intercept method [7].

Microstructural characterization of intermetallic compounds was also carried out by scanning electron microscopy in order to perform punctual and line-scanning chemical analyses, also, to observe surface mesopores formed by vacancy clustering.

X-ray diffraction analyses were performed to determine crystal structure, lattice constants, phases and orientation of specimens. The samples were scanned with a radiation filter $\mathrm{CuK}_{\alpha}$ with a wavelength of $\lambda=1.5418 \AA$, employing a step of $0.02^{\circ}$, in a range of (20 to $120^{\circ}$ of $\left.2 \theta\right)$. These analyses were carried out using a Siemens D5000 difractometer ( $30 \mathrm{kv}, 20 \mathrm{~mA})$. Lattice parameters were determined by least squares method.

Transmission electron microscopy (TEM) was employed to confirm crystal structure and also to characterize nanopores formed by vacancy clustering.
Microhardness Vickers measurements were performed in a Matzusawa microhardness tester. The tensile tests on ribbons were performed on an Instron 1125 Machine, using a deformation rate of $1 \times 10^{-3} \mathrm{~s}^{-1}$.

\section{Results and discussion}

Figure 1 (a), (b) and (c) show melt-spun Fe40Al5Cr ribbons produced at 12,16 and $20 \mathrm{~m} / \mathrm{s}$. Where the melt-spun ribbons produced at 12 and $16 \mathrm{~m} / \mathrm{s}$ exhibit a typical chill microstructure (chill, columnar and equiaxial grains). A drastic reduction of grain size was observed after rapid solidification processing as compared with conventional production methods. The size of equiaxial grains of this ternary ribbons, exhibited a diminution from $24.7 \mu \mathrm{m}$ to $6.61 \mu \mathrm{m}$ as the wheel speed increased from 12 to $20 \mathrm{~m} / \mathrm{s}$, while the width of the columnar grains showed a decrement from 30.4 to $6.4 \mu \mathrm{m}$ with the same wheel speed increment, see Table 1. The thickness of the ribbons underwent a considerable reduction from 75.9 to $25.5 \mu \mathrm{m}$.

A line-scanning chemical analysis performed in spun Fe40Al5Cr ribbons along a length of $3.6 \mu \mathrm{m}$ (3 grains), Fig. 1 (e), revealed a uniform distribution of $\mathrm{Al}, \mathrm{Cr}$ and $\mathrm{Fe}$ along the line as is shown in Figure 1 (d). Thus, it is evident that $\mathrm{Cr}$ is uniformly distributed in the FeAl matrix. So, it can be deduced that $\mathrm{Cr}$ still remains in solid solution after the rapid solidification. Besides, it is well known that rapid solidification processing produces an extended solid solubility of ternary element beyond equilibrium compositions [5]. 

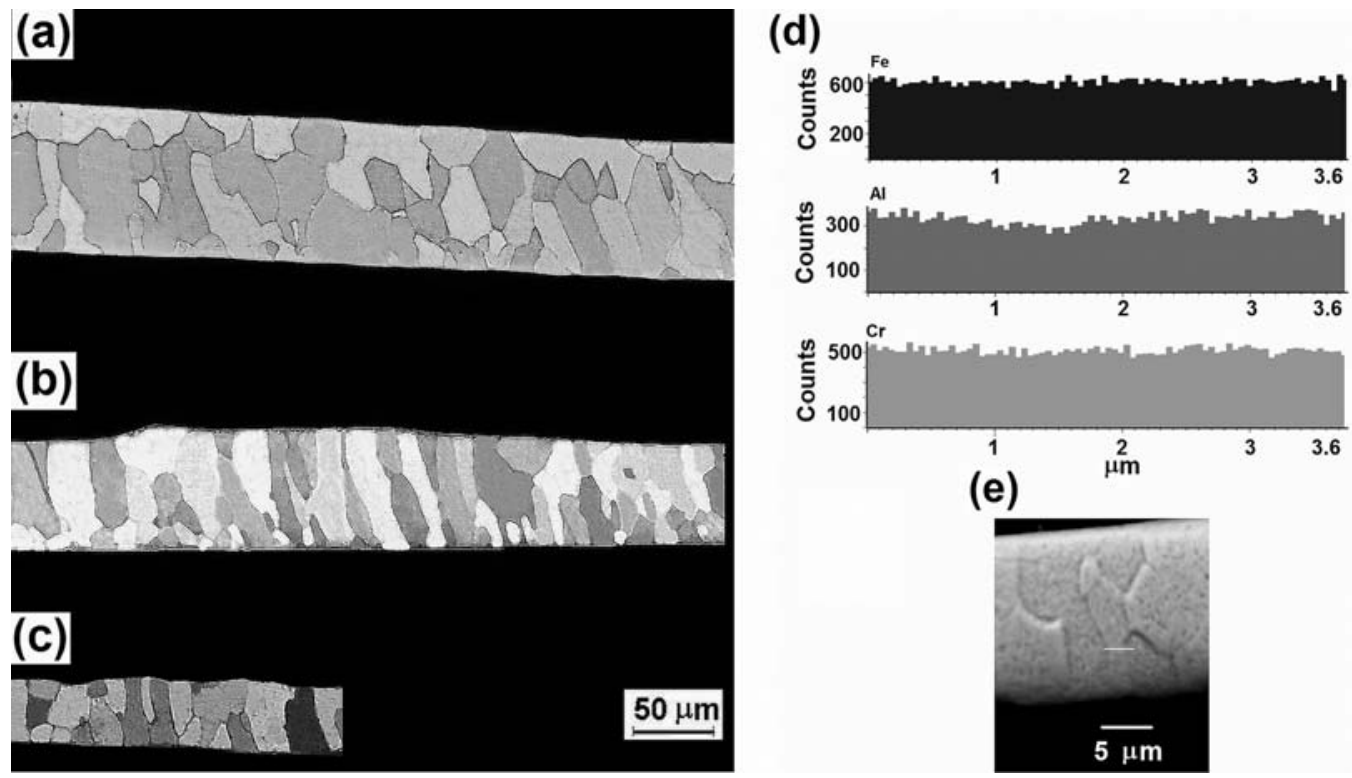

(e)

Figure 1. Scanning electron micrographs of melt spun Fe40Al5Cr (at. \%) ribbons, produced at: a) 12 $\mathrm{m} / \mathrm{s}$ and b) $20 \mathrm{~m} / \mathrm{s}, \mathrm{c}$ ) punctual chemical analysis and, d) scan line chemical analysis along a line of $83 \mu \mathrm{m}$ (4 grains) performed both in melt spun Fe40Al5Cr (at. \%) ribbon.

Figure 2 shows the XRD profiles of melt-spun $\mathrm{Fe} 40 \mathrm{Al} 5 \mathrm{Cr}$, where fundamental (marked with letter f) and super lattice peaks (marked with letter S) are shown, indicating that $\mathrm{Cr}$ does not modify the B2 ordered structure independently of the wheel speed or cooling rate employed to produce the ribbons. Additional peaks of second phases were not detected, indicating that $\mathrm{Cr}$ enters in solid solution in the intermetallic B2 matrix. Ternary FeAlCr ribbons exhibit all diffraction peaks without a notorious orientation, related to a microstructure refinement.

In the same way, A. Agarwal et. al. [8] observed that $\mathrm{Cr}$ and $\mathrm{Ti}$ additions were completely dissolved in a $\mathrm{Fe}_{3} \mathrm{Al}$ intermetallic matrix, without forming second phases or precipitates.

The lattice constants that correspond to the crystal structure B2 type of $\mathrm{Fe} 40 \mathrm{Al} 5 \mathrm{Cr}$ ribbons produced at the wheel speeds of 12 and $20 \mathrm{~m} / \mathrm{s}$, resulted equal to 2.8898 and $2.893 \AA$ Á, respectively, where these lattice constants are minor in comparison to those reported in binary Fe40Al (at. \%) rapid solidified ribbons. R. A. Buckley et. al. [9] reported a lattice constant of 2.9 Á, where the lower values of lattice parameters of ternary $\mathrm{FeAlCr}$ ribbons reported in the present work in comparison with that reported previously [9], is because $\mathrm{Cr}$ occupies the great vacancy sites that are produced during rapid solidification, producing thus a diminution of vacancy and a subsequent decrement of lattice parameter in ternary FeAICr ribbons.

Figure 3 a) shows an electron micrograph corresponding to $\mathrm{Fe} 40 \mathrm{Al} 5 \mathrm{Cr}$ that was produced at a tangential wheel speed of $12 \mathrm{~m} / \mathrm{s}$, where triangular mesopores with a pore size fluctuating between 240 to $940 \mathrm{~nm}$ are shown; Figure 3 (b) shows a pore surface size distribution, where it can be noted that the highest percent of surface area fluctuates between $60 \times 10^{3} \mathrm{~nm}^{2}$ and $100 \times 10^{3} \mathrm{~nm}^{2}$. Various works have reported pore or mesopore formation inside solid B2 intermetallics, such as in NiAl, CoGa [10] and FeAl [11]. Pore formation inside melt-spun ribbons can be originated from vacancy clusters generated during rapid solidification. 


\begin{tabular}{|c|c|c|c|c|c|c|c|}
\hline \multirow{3}{*}{$\begin{array}{c}\text { Alloy } \\
\text { composition } \\
\text { (\% at.) }\end{array}$} & \multirow{3}{*}{$\begin{array}{l}\text { Wheel } \\
\text { speed } \\
(\mathrm{m} / \mathrm{s})\end{array}$} & & & \multicolumn{4}{|c|}{ Grain size $(\mu \mathrm{m})$} \\
\hline & & & & \multicolumn{4}{|c|}{ Longitudinal section, (Grain morphology) } \\
\hline & & Chill & SD ( \pm ) & Equiaxial & SD ( \pm ) & Columnar & SD ( $( \pm)$ \\
\hline $\mathrm{Fe} 40 \mathrm{Al} 5 \mathrm{Cr}$ & 12 & 9.72 & 3.2 & 24.74 & 10.6 & 30.42 & 11.1 \\
\hline $\mathrm{Fe} 40 \mathrm{Al} 5 \mathrm{Cr}$ & 16 & 8.72 & 2.8 & 19.93 & 8.73 & 22.58 & 7.8 \\
\hline $\mathrm{Fe} 40 \mathrm{Al} 5 \mathrm{Cr}$ & 20 & & & 6.61 & 3.05 & 6.48 & 2.61 \\
\hline
\end{tabular}

SD*: (Standard Deviation).

Table 1.Grain sizes of melt-spun Fe40Al5Cr ribbons produced by melt-spinning technique at different wheel speeds $(\mathrm{m} / \mathrm{s})$.

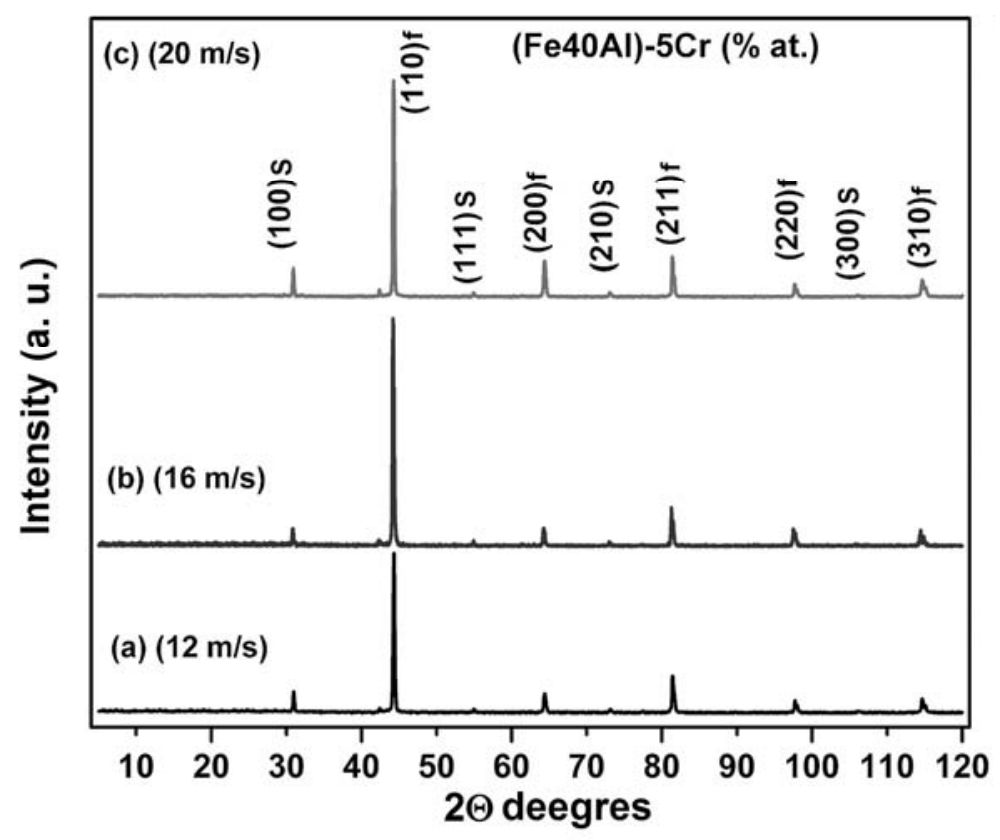

Figure 2. X-ray diffraction profiles of melt spun Fe $40 \mathrm{Al} 5 \mathrm{Cr}$ (\% at.) produced at (a) $12 \mathrm{~m} / \mathrm{s}$ and (b) $20 \mathrm{~m} / \mathrm{s}$. 

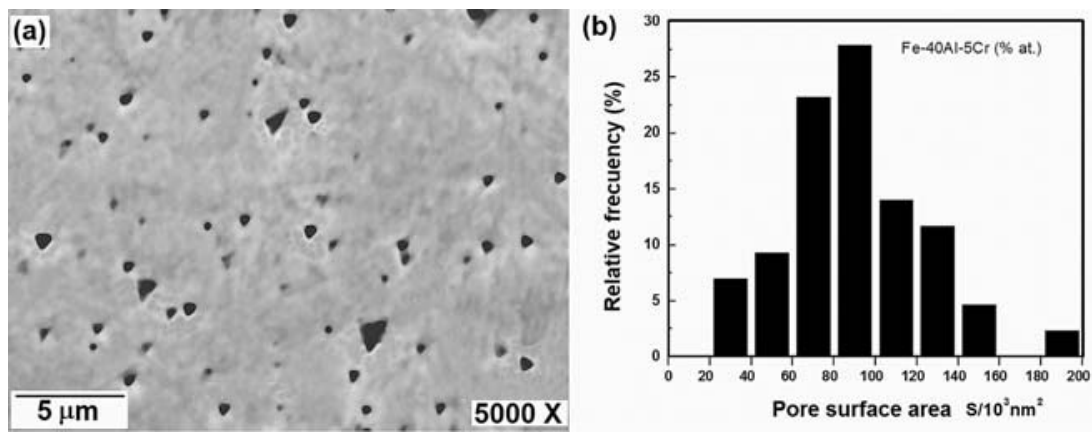

Figure 3. (a) Triangular meso porosity observed in surface of melt spun $\mathrm{Fe} 40 \mathrm{Al} 5 \mathrm{Cr}$ ribbons produced at $12 \mathrm{~m} / \mathrm{s}$, (b) pore surface size distribution obtained by image analysis.

Figure 4 (a) shows features observed inside grains that correspond to nanopore formation by vacancy clustering as those reported by D. G. Morris [12, 13] in a Fe35Al-B2 rapidly solidified alloy. The selected area diffraction patterns confirmed that these rectangular shape features do not correspond to precipitates or inclusions, according to the electron diffraction pattern shown in Figure 4 (b). Figure 4 (a) viewed from [001] zone axis exhibits nanopores with quasi-rectangular morphology together with straight border dislocations with burgers vectors parallel to $<001>$. One side of the rectangles shown in Figure 4 (a) is parallel to the (100) plane and the other side is parallel to the (010) plane.

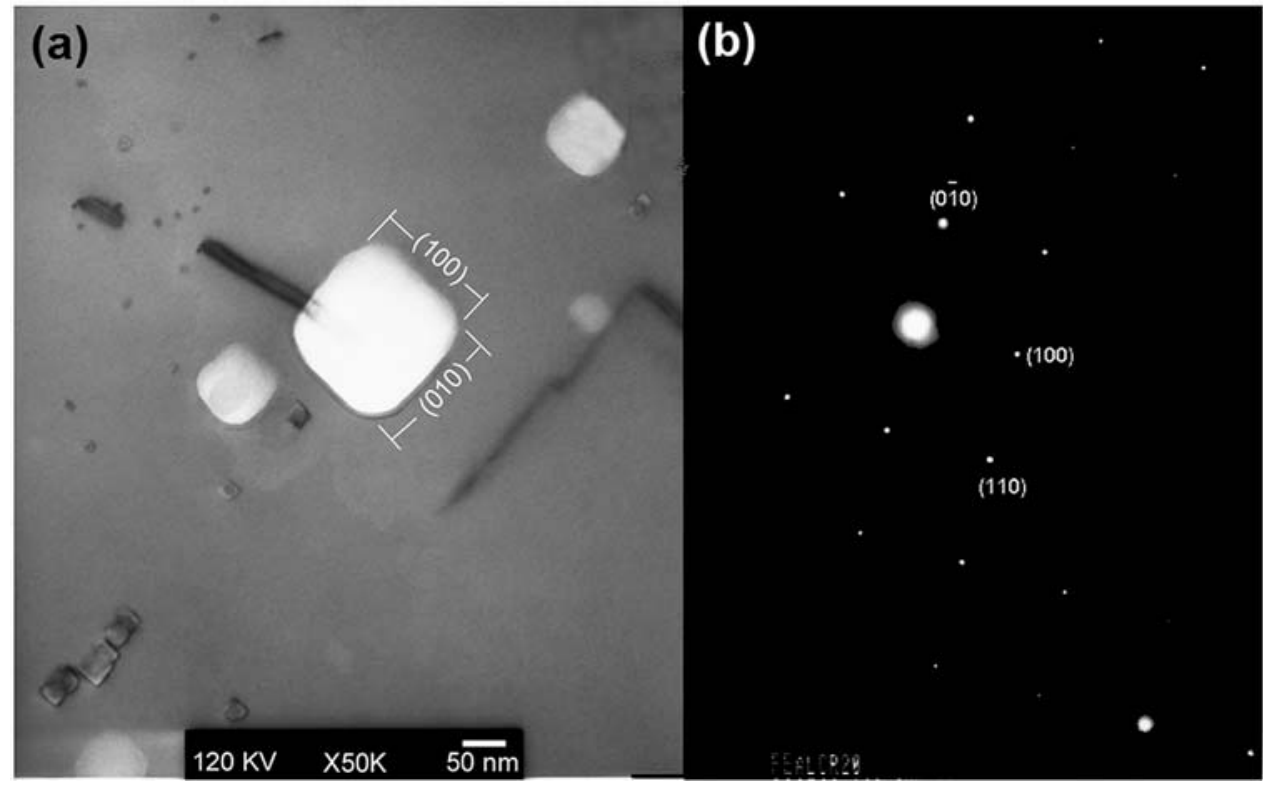

Figure 4. Transmision electron micrograph of melt spun Fe40Al5Cr ribbon produced at $20 \mathrm{~m} / \mathrm{s}$ wheel speed.

(a) nanopore formation by vacancy clustering together with $<001>$ dislocations, (b) electron difraction pattern viewed from [001] zone axis corresponding to micropore. 


\begin{tabular}{ccc}
\hline $\begin{array}{c}\text { Alloy Composition, (at. } \\
\%)\end{array}$ & $\begin{array}{c}\text { Production condition, } \\
\text { Wheel speed (m/s) }\end{array}$ & Micro hardness Vickers (Hv) \\
\hline Fe-40Al-5Cr & 12 & 393.8 \\
\hline Fe-40Al-5Cr & 16 & 352.9 \\
\hline Fe-40Al-5Cr & 20 & 379.2 \\
\hline
\end{tabular}

Table 2.Microhardness Vickers (Hv) of rapidly solidified FeAlCr ribbons.

Table 2 shows microhardness Vickers measurements that correspond to $\mathrm{FeAlCr}$ alloys produced at different wheel speeds, where a variation from 353 to $393 \mathrm{Hv}$ is observed. Besides, these ternary alloys in as-spun condition exhibited lower values than other binary Fe40Al rapidly solidified ribbons whose values where reported previously [14], where this softening observed in melt-spun FeAlCr ribbons is mainly due to the reduction of the great concentration of retained vacancies quenched from elevated temperatures at high cooling rates, by means of the vacancy site occupation of $\mathrm{Cr}$ element.

Table 3 shows strength and elongation values corresponding to $\mathrm{Fe} 40 \mathrm{Al} 5 \mathrm{Cr}$ ribbons. Where the resistance to failure resulted in 245, 139 and 90 $\mathrm{MPa}$, and the elongation resulted in 2.3, 0.94 and $1.507 \%$ for the ribbons produced at 12,16 and 20 $\mathrm{m} / \mathrm{s}$, respectively. It is important to notice that the ductility of the FeAlCr alloy produced at $12 \mathrm{~m} / \mathrm{s}$ turned out to be major than the one observed in other alloys produced previously by conventional production methods.

O. Klein [6] and collaborators performed tension tests in air at room-temperature in Fe40Al5Cr (\% at.) alloys that were doubly extruded at $(1273 \mathrm{~K}$, $7: 1$ and $1023 \mathrm{~K}, 6: 1)$ and annealed at $660{ }^{\circ} \mathrm{C} / 2$ days $+400{ }^{\circ} \mathrm{C} / 120 \mathrm{~h}$. They observed elongations of $2 \%$ and $2,2 \%$ in the alloys with grain size of $5 \mu \mathrm{m}$ at deformation rates of $1 \times 10^{-6}$ and $1 \times 10^{-4} \mathrm{~s}^{-1}$, respectively. These values are slightly smaller to the observed in $\mathrm{Fe} 40 \mathrm{Al} 5 \mathrm{Cr}$ ribbons produced at 12 $\mathrm{m} / \mathrm{s}$ in the present work. Nevertheless, O. Klein and collaborators observed particles of $\mathrm{Cr}_{2} \mathrm{Al}$ in the surfaces of fracture, which originate an increment in yield and fracture strength with a combined reduction of elongation to fracture. So, the higher elongation to failure corresponding to the ribbon produced at $12 \mathrm{~m} / \mathrm{s}$ is due to the absence of second-phase particles that could act as obstacles to the movement of dislocations. 


\begin{tabular}{|c|c|c|c|c|}
\hline $\begin{array}{c}\text { Alloy } \\
\text { composition, } \\
\text { (at. \%) }\end{array}$ & $\begin{array}{c}\text { Production } \\
\text { condition }(\mathrm{m} / \mathrm{s})\end{array}$ & $\begin{array}{c}\text { Fracture } \\
\text { strength }(\sigma) \\
\mathrm{MPa}\end{array}$ & Elongation (\%) & Failure mode \\
\hline $\mathrm{Fe}-40 \mathrm{Al}-5 \mathrm{Cr}$ & 12 & 245.05 & 2.3 & $\begin{array}{l}\text { Mixed IG }{ }^{*}+ \\
\text { TG }^{*}\end{array}$ \\
\hline $\mathrm{Fe}-40 \mathrm{Al}-5 \mathrm{Cr}$ & 16 & 139.746 & 0.944 & $\begin{array}{l}\text { Mixed } \mathrm{IG}^{*}+ \\
\mathrm{TG}^{*}\end{array}$ \\
\hline $\mathrm{Fe}-40 \mathrm{Al}-5 \mathrm{Cr}$ & 20 & 90.562 & 1.507 & $\begin{array}{l}\text { Mixed } \mathrm{IG}^{*}+ \\
\mathrm{TG}^{*}\end{array}$ \\
\hline IG*: Intergra & ar; TG* : Transg & ular & & \\
\hline
\end{tabular}

Table 3. Mechanical properties of melt-spun FeAICr alloys.

All ternary FeAlCr ribbons exhibited a mixed (IG + TG) fracture mode. Figure 5 shows fracture surfaces of melt-spun Fe40Al5Cr ribbons produced at 12,16 and $20 \mathrm{~m} / \mathrm{s}$, respectively. A decrease of transgranular percent of area from 10.73 to $2.5 \%$ with the increment in wheel speed was observed. This behavior can be explained in terms of the quantity of retained vacancies that were produced after the rapid cooling since the increase in the cooling rate rises the quantity of non-equilibrium vacancies, in the same way, the resistance of the material in the interior of the grains is increased simultaneously, promoting thus a proportional increment in the intergranular mode of failure. Similarly, [15] Schneibel et. al., reported a transgranular area percent of $8 \%$ in an $\mathrm{Fe} 45 \mathrm{Al} 5 \mathrm{Cr}$ alloy extruded at (1173 K, 9:1) with a thermal treatment at $673 \mathrm{~K} / 178 \mathrm{~h}$, where this result is consistent with the fractographic analysis performed in the present work.
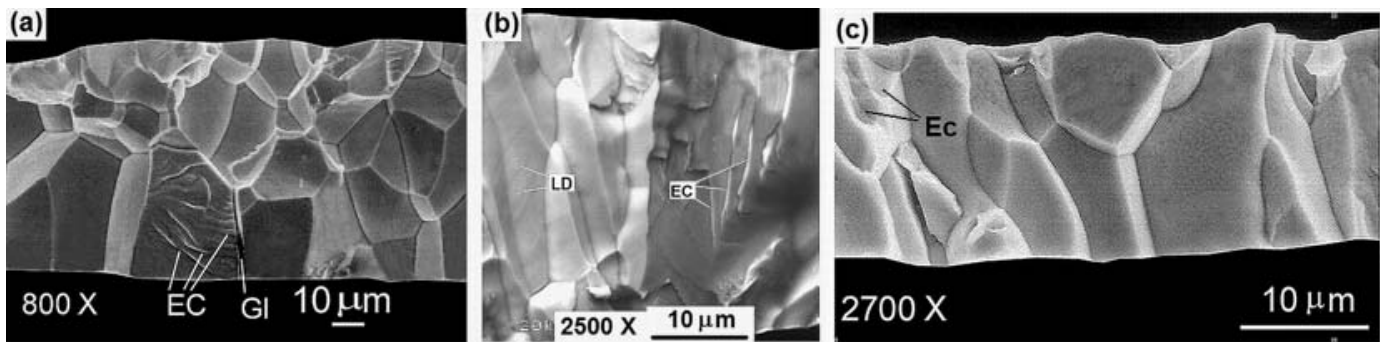

Figure 5.Surface fractures of melt spun Fe40Al5Cr (at. \%) produced at a) 12, b) 16 and c) 20 m/s. 


\section{Conclusion}

The grain size and ribbon thickness showed a considerable reduction when the wheel speeds was increased from 12 to $20 \mathrm{~ms}^{-1}$.

$\mathrm{Cr}$ element remain in solid solution in FeAl matrix, as the XRD analyses revealed, finding that chromium is uniformly distributed among the whole melt spun FeAlCr ribbon, as the linescanning chemical analysis revealed.

Lattice constants of ternary $\mathrm{FeAlCr}$ ribbons resulted in lower values than those reported in rapid solidified binary Fe40Al ribbons, where this behavior is because chromium occupies the great quantity of vacancy sites that are produced upon rapid solidification processing.

Quasi rectangular nanopores were formed inside the ternary FeAlCr ribbons, where one side of this square nanopores is parallel to the (100) plane and the other side is parallel to the (010) plane.

Hardness measurements revealed a softening in rapidly solidified $\mathrm{FeAlCr}$ ribbons as compared with rapidly solidified binary Fe40Al due to a diminution of the great concentration of retained vacancies quenched from high temperatures at elevated cooling rates, by means of the vacancy site occupation of $\mathrm{Cr}$ element.

The tensile test exhibited a mixed mode of fracture (transgranular + intergranular) by increasing the intergranular failure mode as the wheel speed or cooling rate increased.

The highest tensile ductility observed corresponds to melt-spun ribbons rapidly solidified at $12 \mathrm{~m} / \mathrm{s}$, reaching a value of $2.3 \%$, where this deformation capability is greater than other alloys with the same composition and structure that were fabricated by extrusion.

\section{References}

[1] J. H. Westbrook, R. L. Fleischer, editors. Intermetallic compounds: vol. 1, Principles, J. Wiley and Sons Ltd., New York, 1994, pp. 977-1016.

[2] P. F. Tortorelli, K. Natesan, Critical Factors Affecting the High-Temperature Corrosion Performance of Iron Aluminides, Materials Science and Engineering, Vol. A258, 1998, pp.115-125.

[3] N.S. Stoloff, V.K. Sikka, Physical Metallurgy and Processing of Intermetallic Compounds, Chapman \& Hall, 1996, pp. 56-89

[4] R. Balasubramaniam, Alloy Development to Minimize Room Temperature Hydrogen Embrittlement in Iron Aluminides, Journal of Alloys and compounds, Vol. 31, 1997, pp. 148-151.

[5] H. Jones, Rapid Solidification of Metals and Alloys. The Institute of Metallurgist. Monograph No. 8: 1982.

[6] O. Klein and I. Baker, Effect of Chromium on The Environmental Sensitivity of FeAl at Room Temperature, Scripta Metallurgica et Materialia, Vol. 27, 1992, pp. 1823-1828.

[7] Annual Book of ASTM Standards, Metals Test Methods and Analytical Procedures, Vol. 03.01, 1993, ASTM, pp. 304-309.

[8] A. Agarwal, M. J. Akthar and R. Balasubramaniam, Effect of alloying on aqueous Corrosion and Mechanical Behaviour of Iron Aluminide Fe3Al, Journal of Materials Science, Vol. 31, 1996, p. 5207.

[9] R. A. Buckley and S. Kaviania, Some aspects of Rapid Solidification Processing of Fe-Al-X alloys, Materials Science and Engineering, Vol. A258, 1998, pp. 173-180.

[10] R. Nakamura, K. Yoshimi, S. Tsurekahua, Supersaturated Vacancies and Vacancy Complexes in Rapidly Solidified B2 Aluminide Ribbons, Materials Science and Engineering: A, Vols. 449-451, 2007, pp. 1036-1040 
[11] K. Yoshimi, S. Hanada, T. Haraguchi, H. Kato, T. Itoi and A. Inoue, Nanoporous surfaces of FeAl formed by vacancy clustering, Materials Transactions, Vol. 43, No. 99, 2002, pp. 2897-2902.

[12] D. G. Morris and M. A. Morris, Mechanical Properties of FeAl-ZrB2 Alloys Prepared by Rapid Solidification, Acta Metallurgica et Materialia, Vol. 39, No. 8, 1991, pp. 1771-1779.

[13] D. G. Morris and M. A. Morris, Rapid Solidification of FeAl intermetallics containing ZrB2, Materials Science and Engineering, Vol. A134, 1991, pp. 1129-1132

[14] R. A. Rodríguez D., Ph. D., Thesis, UNAM, (2009).

[15] J. H. Schneibel, E. P. George and I. M. Anderson, Tensile Ductility, Slow Crack Growth, and Fracture Mode of Ternary B2 Iron Aluminides at Room Temperature, Intermetallics, Vol. 5, 1997, pp. 185-193.

\section{Acknowledgment}

This work was supported by CONACYT-Mexico. The authors also acknowledge the contribution of Techs. A. Maciel, S. García, L. Baños López, C. Flores Morales, E. Sanchez Colin, R. Hernández, A. Flores during the experimental work. 


\section{Authors Biography}

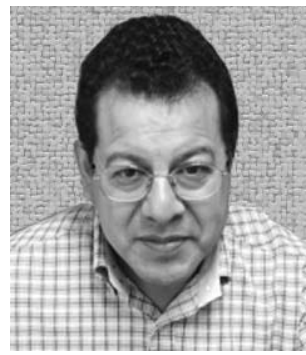

\section{Julio Alberto JUÁREZ-ISLAS}

He obtained his degree in chemical metallurgical engineering in 1980 from Universidad Nacional Autónoma de México. In 1982, he obtained the graduate degree in metallurgy in the Department of Metallurgy of the University of Sheffield, England and in 1986, his doctorate degree in metallurgy in the School of Materials of the University of Sheffield, England. In April 1989, he joined the Institute of Physics in Cuernavaca as a level C associate researcher and in 1994 he was transferred to the Instituto de Investigación en Materiales of the UNAM. At the moment, he is a regular level C full-time senior research, a level 3 researcher of the National System of Researchers and a level $D$ researcher in the academic personnel acting. Because of his involvement with the industrial sector, in 2001 he was named Coordinator of the University Program for Science and Engineering of Materials.

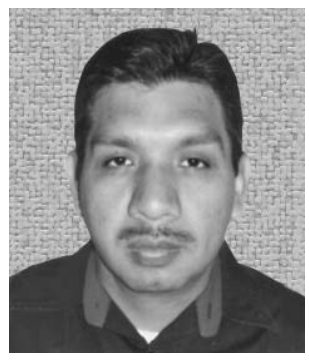

\section{Miguel Angel SUÁREZ-ROSALES}

He obtained his bachelor's degree in metallurgical engineering from Universidad Autónoma Metropolitana (Azcapotzalco) and his master's degree in science and engineering of materials from the Instituto de Investigación de Materiales. Recently, he completed his PhD studies in engineering at the Faculty of Chemistry (UNAM) in March 2009. His main research area is the solidification of ferrous and non ferrous alloys.

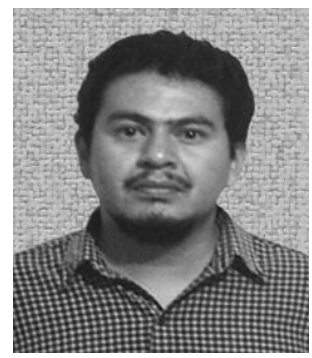

\section{Roberto Ademar RODRÍGUEZ-DÍAZ}

Dr. Roberto A. Rodríguez Díaz obtained his bachelor's degree in mechanical engineering from the Universidad del Estado de Michoacán with the support of a scholarship provided by the university to outstanding students. He then earned his master's degree from the Instituto Tecnológico de Morelia with the thesis entitled "Kinetic and Thermodynamic Study of the Reduction of Hematite with H2, Co and H2/Co Mixtures at Low Temperatures". Finally, Dr. Rodríguez obtained his PhD degree from the UNAM (Universidad Nacional Autónoma de México) with the thesis entitled "Rapid Solidification Processing of FeAl Intermetallic Compounds - Microstructure and Mechanical Properties". His research interests are related with rapid solidification, intermetallic compounds, iron oxide reduction, microstructural characterization. 


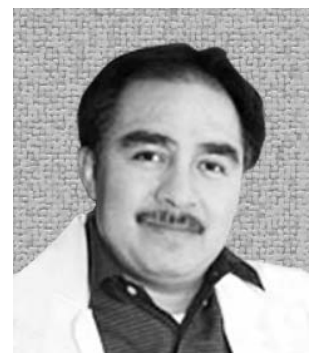

\section{Jesús Angel ARENAS-ALATORRE}

He got his bachelor's degree as a physician and a master's degree in materials science from UNAM. He concluded his PhD studies in physics of materials at the CICESE, He has performed research activities in the Microscopy Laboratory (Argonne National Laboratory). He is a level 1 member of the National System of Researchers (SNI) in Mexico. His research interests are in the study of nanometric materials with catalytic, optical and magnetic properties. He has published more than 30 investigation papers in indexed magazines. Additionally, Dr. Arenas is a member of the Mexican Academy of Science and he is currently the vicepresident of the Mexican Association of Microscopy.

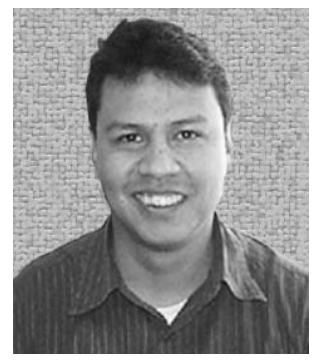

\section{Jesús Mario COLÍN DE LA CRUZ}

He got his master's and PhD degrees from the Chemistry Faculty of UNAM (Universidad Nacional Autónoma de México). He completed a postdoctoral stay at the Physical Sciences Institute which is incorporated to the UNAM. His research interests are in rapid solidification, intermetallic compounds and coatings. He is a professor at the UAEM in Mexico.

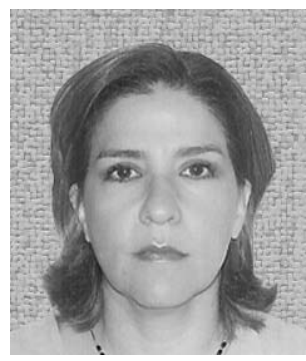

\section{M.G. GARNICA-ROMO}

She is a professor-researcher at the Universidad Michoacana de San Nicolás de Hidalgo in Mexico.

Her research interests are in materials processing, coatings, materials characterization, optical properties and dielectric and piezoelectric materials. She has published more than eighteen papers in international journals, proceedings and conferences. 